\title{
Performance of the Constructed Wetland System for the Treatment of Water from the Corumbataí River
}

\author{
Ana Kleiber Pessoa Borges ${ }^{1}$, Sâmia Maria Tauk-Tornisielo ${ }^{1 *}$, Roberto Naves Domingos ${ }^{1}$ \\ and Dejanira de Franceschi de Angelis ${ }^{2}$ \\ ${ }^{1}$ Centro de Estudos Ambientais; Universidade Estadual Paulista; Av. 24A, 1515; seb@rc.unesp.br; 13506-900; Rio \\ Claro - SP - Brasil. ${ }^{2}$ Departamento de Bioquímica e Microbiologia; Instituto de Biociências; Universidade Estadual \\ Paulista; dangelis@rc.unesp.br; 13506-900; Rio Claro - SP - Brasil
}

\begin{abstract}
The aim of this work was to study the constructed wetland system for the treatment of water from the Corumbatai river simulated on a laboratory scale. The parameters analyzed at different points of the system were ammonia, biochemical demand for oxygen (BDO), chemical demand for oxygen (CDO), chlorides, apparent color, conductivity, dissolved oxygen, magnesium ( $\mathrm{Mg})$, sodium $(\mathrm{Na})$, potassium $(\mathrm{K})$, silicon (Si), total phosphorous, total coliforms and Escherichia coli, total dissolved solids (TDS), turbidity, and macrophyte biomass. The results demonstrated that this alternative water treatment system was effective in removing the microorganisms (total coliforms and E. coli), among other parameters analyzed, for varying periods of the treatment, promoting notable improvement in the quality of the water treated from the Corumbatai River.
\end{abstract}

Key Words: Aquatic macrophytes, filtering soil, microfiltration, bioreactor, microorganisms

\section{INTRODUCTION}

Water has become increasingly scarce due to the lack of urban planning, rapid increase in the pollution, waste, and the lack of water re-usage and effective environmental education programs. Water use regulation was proposed as an useful tool in beginning discussion of water quality goals according classification system proposed by the CONAMA resolution (Souza and Tundisi, 2003). The high cost of implementing the basic sanitation projects can lead to higher public debt and compete for the resources that are badly needed for other essential services, such as the health and education (Rebouças et al., 1999). The efforts to develop the projects that are both low cost and effective have, paradoxically, been more intensive in the wealthier countries of Europe and the United States, since 1970. Some proposals for the effluent and water treatment exist in literature, amongst these, of the use of ultrasound for the reduction of the number of the bacteria (Domingos et al., 2005). An alternative process for treating the water, effluents, and domestic sewage is the CWs (constructed wetland system) (Salati et al., 1999). Despite evidence of the toxic effects on the aquatic plants when the effluent has a high organic load (Haynes and Goh, 1978; Gersberg et al., 1986), these CWs have been used as the secondary and tertiary treatments (Green et al., 1996; Stober et

\footnotetext{
Author for correspondence
} 
al., 1997; Neralla et al., 1998; Billore et al., 1999), and can be used for the primary treatment of the water or effluents as an alternative to the traditional process currently in use. Furtado et al., 2002 investigated the methanogenic activity in sediment of the Imboacica (human impacted), Cabiúnas and Comprida coastal lagoons in Rio de Janeiro State (Brazil).

The use of CWs to treat the river water and residual water has been studied in a number of countries (Hammer, 1989; Cooper and Findlater, 1990; Olson and Marshall, 1992; Moshiri, 1993; Kadlec and Knight, 1996), and the problems associated with it have also been studied (Pant et al., 2001; Gómez Cerezo et al., 2001; Braskerud, 2002a,b; Söderqvist, 2002; Pant and Reddy, 2003). The use of the aquatic macrophytes in the CWs has been proven for reducing the amount of the organic matter (Brix, 1993; Nguyen, 2000), remove the nutrients (Mitsch et al., 2000), and reduce the pathogens (Perkins and Hunter, 2000). In Brazil, this treatment has been questioned with respect to its efficiency and cost/benefit; nevertheless, based on the studies by Carmen Lúcia Roquette Pinto, of the Universidade Federal Fluminense, and findings presented at the $6^{\text {th }}$ International Conference on the Wetland Systems for Water Pollution Control, in Águas de São Pedro, São Paulo (SP), 1998, it has gradually become a subject of study. In this study, we sought to verify, on a laboratory scale, the efficiency of descending flow CWs containing particulates, microorganisms, macroorganisms, peat, and inert industrial residues, for the treatment of water from the Corumbataí River in Rio Claro, SP.

\section{MATERIALS AND METHODS}

The collection site for the water samples from the Corumbataí River was in the district of Assistência, in the municipality of Rio Claro, SP, UTM coordinates X 230064 and Y 7507759. One thousand five hundred liters of water were collected for use in the CW system, with physicalchemical properties (Palma-Silva and TaukTornisielo, 2001) that placed them in class 4, according to CONAMA Resolution 357/2005 (CONAMA, 2005).

The CWs was constructed in 250L PVC boxes in a series of 4 tanks (reactors), in a continuous flow. The following was placed in each reactor, as illustrated in Figure 1: reactor 1, class 4 water from the Corumbataí River; reactor 2, floating aquatic macrophyte Eichhornia crassipes, covering $80 \%$ of the water surface; reactor 3 , three different sizes of gravel $(a=25-50 \mathrm{~mm} ; b=6,4-$ $12,7 \mathrm{~mm} ; \mathrm{c}=2,4-4,8 \mathrm{~mm}$ ), plus soil of cerrado area and Si residue; reactor 4, the same three sizes of gravel as in reactor 3, plus soil of cerrado area and peat. Four collection points were established in the system, at the exits of reactor $1(\mathrm{P} 1)$, reactor $2(\mathrm{P} 2)$, reactor $3(\mathrm{P} 3)$, and reactor $4(\mathrm{P} 4)$. At each collection point, $1 \mathrm{~L}$ of water was sampled, with $0.1 \mathrm{~L}$ being used for the analyses of microbiological parameters, carried out by the Centro de Estudos Ambientais (CEA - Center for Environmental Studies) at UNESP, Rio Claro, SP. Water samples were collected from the CWs for a period of 20 days, with the first being conducted two hours after the experiment was initiated (T0). The T10 samples were collected on the $10^{\text {th }}$ day of the experiment, T15 on the $15^{\text {th }}$, and T20 twenty days after the experiment began. The samples were collected in $1 \mathrm{~L}$ polyethylene bottles and cooled in a Styrofoam box. The analyses of the samples were conducted on the same day they were collected, with the exception of the total nitrogen analysis, for which the samples were acidified and kept refrigerated for later quantification. Collection flasks $(100 \mathrm{~mL})$, tightly closed with stoppers wrapped in protective paper, were previously sterilized for the microbiological analyses of the samples.

The physical, chemical, and microbiological parameters were determined using the methodology established in Standard Methods for the Examination of Water and Wastewater (1998) for the analysis of ammonia, biochemical demand for oxygen (BDO), chemical demand for oxygen (CDO), chlorides, apparent color, conductivity, dissolved oxygen, $\mathrm{Mg}, \mathrm{Na}, \mathrm{K}, \mathrm{Si}$, total phosphorous, total dissolved solids (TDS), and turbidity. Total coliforms and Escherichia coli were determined using Colilert kits (IDEXX Laboratories Inc. Westbook, ME).

The biomass of macrophyte was determined by gram (dry weight) throughout the experiment (Elias et al., 2001). Samples were taken to quantify the biomass at T0, T5, T10, T15, and T20. At the time the aquatic macrophytes were taken from reactor 2 (Fig. 1), they were weighed after 5 minutes to allow the drainage of excess water (fresh weight). The dry weight of the plants was obtained after 48 hours at $72^{\circ} \mathrm{C}$. 


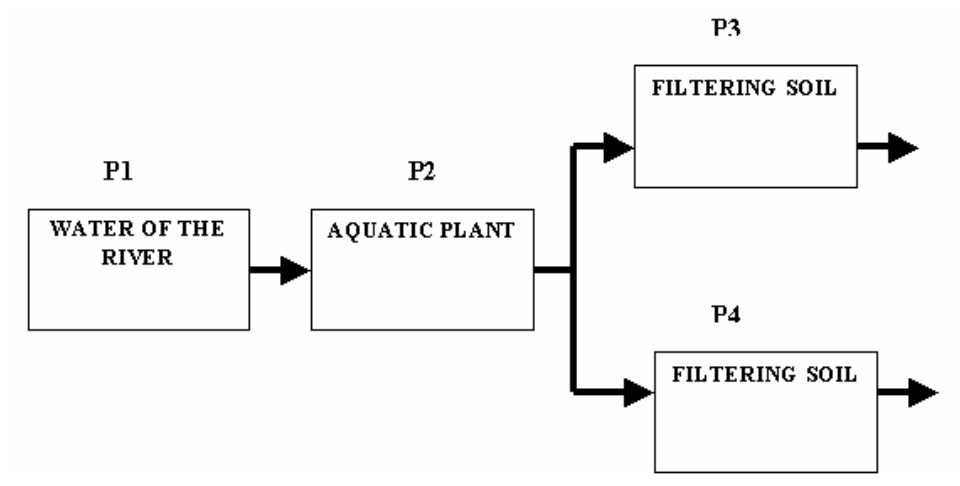

Figure 1 - Diagram of the constructed wetland system for the treatment of water from the Corumbataí River. Legend: P1 = Reactor 1; P2 = Reactor 2; P3 = Reactor 3 and P4 = Reactor 4

\section{RESULTS AND DISCUSSION}

\section{Growth rate of the macrophytes}

The results regarding the growth rate of the macrophytes during the 20 days of the experiment are presented in Figure 2. The macrophytes showed growth in the CWs during the experiments with treatment of water from the Corumbataí River, however great variation was observed in the mean dry weight of the samples, as evidenced by the large standard deviation in the statistical analyses - a fact that was also observed by Elias et al. (2001). Various environmental factors may have contributed to this result, such as the size of the space available for the plants in the reactor, increasing the competition for the nutrients and light in the system. Despite the large standard deviations, an increase in the biomass of the plants can be observed in the CWs. This increase can be attributed to the assimilation by the aquatic plants of the nutrients provided by the river water.

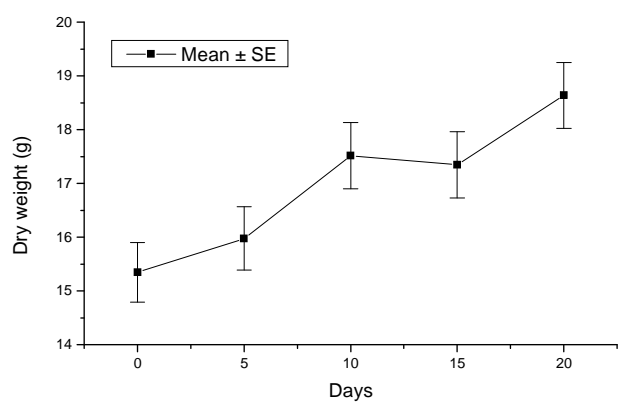

Figure 2 - Growth curve of Eichhornia crassipes determined for the amount of biomass (dry weight) in the CW system during the treatment of the water of the River Corumbataí.

\section{Water analyses}

The results of the analyses samples water at $\mathrm{T} 0$, $\mathrm{T} 5, \mathrm{~T} 10, \mathrm{~T} 15$, and $\mathrm{T} 20$ are presented in Tables 1 , 2, 3 and 4 . The results obtained at T0 (Table 1) demonstrate that the best performance for almost all the parameters studied occurred in the system composed of reactor 4, containing aquatic macrophyte, and three sizes of gravel plus soil and peat. Efficiency greater than $80.0 \%$ was observed for turbidity, total phosphorous, $\mathrm{Mg}$, total coliforms and E. coli. The system composed of reactor 3 also had greater than $95.0 \%$ efficiency for total coliforms and E. coli. Elias et al. (2001) found $87.0 \%$ efficiency in the reduction of ammonia in a $\mathrm{CW}$ system using floating aquatic plants (Eichhornia crassipes) and rice, while Jing et al. (2001) obtained 78.0-100.0\% efficiency in the reduction of ammonia in a similar system used to treat river water. These results had presented better comparative efficiencies when to those 
obtained here with the use of E. crassipes, only. Thus, the results obtained here could be optimized with mixing cultures of this floating aquatic plant with other similar plants to the rice.

Table 1 - Analyses of water parameters of Corumbataí River, in period T0 days, in CWs. Legend: P1 = Reactor 1; $\mathrm{P} 2=$ Reactor $2 ; \mathrm{P} 3=$ Reactor $3 ; \mathrm{P} 4=$ Reactor 4 and $\mathrm{E}=$ Efficiency.

\begin{tabular}{|c|c|c|c|c|c|c|c|}
\hline Parameters & P1 & $\mathbf{P 2}$ & E. $(\%)$ P1-P2* & P3 & E. (\%) P1-P3** & P4 & E. $(\%)$ P1-P4*** \\
\hline Water temperature ${ }^{\circ} \mathrm{C}$ & 27.1 & 26.5 & - & 27.2 & - & 27.4 & - \\
\hline Ambient temperature ${ }^{\circ} \mathrm{C}$ & 33.5 & 33.5 & - & 33.5 & - & 33.5 & - \\
\hline Turbidity (UNT) & 30.3 & 13.8 & 54.5 & 18.6 & 38.6 & 3.6 & 88.1 \\
\hline Conductivity $\left(\mu \mathrm{S}_{\mathrm{Cm}}{ }^{-1}\right)$ & 193.0 & 186.0 & 3.6 & 191.0 & 1.0 & 157.0 & 18.7 \\
\hline $\mathrm{pH}$ & 7.1 & 6.5 & - & 6.5 & - & 6.1 & - \\
\hline Total nitrogen (mg.L $\left.\mathrm{L}^{-1}\right)$ & 10.1 & 9.8 & 3.0 & 9.8 & 3.0 & 9.1 & 9.9 \\
\hline Dissolved oxygen $\left(\mathrm{mg} . \mathrm{L}^{-1}\right)$ & 9.0 & 8.9 & - & 9.0 & - & 9.2 & - \\
\hline Ammonia $\left(\mathrm{mg} \cdot \mathrm{L}^{-1}\right)$ & 1.4 & 0.5 & 64.3 & 0.4 & 71.4 & 0.4 & 71.4 \\
\hline $\mathrm{CDO}\left(\mathrm{mg} \cdot \mathrm{O}_{2} \cdot \mathrm{L}^{-1}\right)$ & 22.5 & 28.5 & -26.7 & 40.0 & -77.8 & 19.0 & 15.6 \\
\hline $\mathrm{BDO}\left(\mathrm{mg} \cdot \mathrm{O}_{2} \cdot \mathrm{L}^{-1}\right)$ & 14.1 & 12.1 & 14.2 & 11.4 & 19.1 & 8.4 & 40.4 \\
\hline Apparent color $(\mathrm{Pt} / \mathrm{L})$ & 186.5 & 107.5 & 42.4 & 91.5 & 50.9 & 46.0 & 75.3 \\
\hline Total Phosphorus $\left(\mu \mathrm{g} \cdot \mathrm{L}^{-1}\right)$ & 200.0 & 82.2 & 58.9 & 79.6 & 60.2 & 22.7 & 88.7 \\
\hline Chlorides (mg. $\left.\mathrm{L}^{-1}\right)$ & 8.5 & 21.0 & -147.1 & 34.0 & -300.0 & 31.0 & -264.7 \\
\hline TDS (mg. $\left.\mathrm{L}^{-1}\right)$ & 96.0 & 93.5 & 2.6 & 98.5 & -2.6 & 78.0 & 18.8 \\
\hline $\mathrm{Na}\left(\mathrm{mg} \cdot \mathrm{L}^{-1}\right)$ & 9.0 & 6.1 & 32.2 & 4.1 & 54.4 & 3.2 & 64.4 \\
\hline $\mathrm{K} \quad\left(\mathrm{mg} . \mathrm{L}^{-1}\right)$ & 2.4 & 1.8 & 25.0 & 0.9 & 62.5 & 1.3 & 45.8 \\
\hline $\mathrm{Si} \quad\left(\mathrm{mg} \cdot \mathrm{L}^{-1}\right)$ & 6.9 & 5.8 & 15.9 & 10.8 & -56.5 & 4.2 & 39.1 \\
\hline $\mathrm{Ca}\left(\mathrm{mg} \cdot \mathrm{L}^{-1}\right)$ & 9.7 & 16.1 & -66.0 & 22.6 & -133.0 & 16.2 & -67.0 \\
\hline $\operatorname{Mg}\left(\mathrm{mg} \cdot \mathrm{L}^{-1}\right)$ & 8.2 & 4.9 & 40.2 & 2.0 & 75.6 & 1.6 & 80.5 \\
\hline Total coliforms MNP/100 mL & $1.0 \times 10^{5}$ & $3.0 \times 10^{4}$ & 70.0 & $1.1 \times 10^{3}$ & 98.9 & $3.6 \times 10^{3}$ & 96.4 \\
\hline E. coli $\mathrm{MNP} / 100 \mathrm{~mL}$ & $1.6 \times 10^{4}$ & $6.4 \times 10^{3}$ & 60.0 & $1.0 \times 10^{1}$ & 99.9 & $3.1 \times 10^{2}$ & 98.1 \\
\hline
\end{tabular}

Variation in the percentage of reduction of CDO has been found in different types of CWs. The results shown in table 1 show to minor efficiencies in relation to those finding in the T10 period (Table 2) and of other authors, mainly in reactor 4. Koottatep and Polprasert (1997) obtained 71.0\% (1 day) and $83.0 \%$ (5 days) efficiency in the reduction of CDO, and Manfrinato (1989), using the edapho-phytodepuration method, obtained 84.0 $\%$ efficiency using only aquatic plants. Solano et al. (2004) using this system in small villages, achieved $50.0 \%$ and $88.0 \%$ efficiency in the reduction of $\mathrm{CDO}$ in October and summer, respectively. In the $\mathrm{CWs}$ used by Schulz et al. (2004), there was 30.0-31.0\% efficiency in the reduction of $\mathrm{CDO}$ after 56 and 98 days, respectively. Lee et al. (2004), in a system with three periods of hydraulic retention (HRT), obtained $84.0 \%$ efficiency in phase I (1 to 109 days), with lower values at longer periods of time.
The results found in the systems CWs showed the efficiency with the maximum of $75.0 \%$ reduction in CDO after 10 days of treatment with the reactor 4 (Table 2). Values exceeding $80.0 \%$ efficiency were obtained for turbidity, total phosphorous, total coliforms, and E. coli in the system composed of reactor 4. More than $100.0 \%$ efficiency in the reduction of most probable number of $E$. coli occurred at T10, T15, and T20, with the greatest reduction in total coliforms (99.9\%) occurring at T10 and T15.

With regard to nitrogen, maximum performance $(14.3 \%)$ was achieved in the system when the water passed through reactor $\mathrm{P} 4$, containing gravel, soil, and peat, after 20 days of treatment (T20). Koottatep and Polprasert (1997) obtained $84.0-86.0 \%$ efficiency in the removal of total nitrogen at 8 weeks of treatment; Schultz et al (2004) reported $19.0 \%$ efficiency at 14 days and $30.0 \%$ at 70 days; Lee et al. (2004) obtained 
$24.0 \%$ efficiency in phase I, with lower rates of efficiency in the other two phases. All the results presented for these authors had greater efficiencies in relation to those finding in the system used here.

Table 2 - Analyses of water parameters of Corumbataí River, in period T10 days, in CWs. Legend: P1 = Reactor 1; P2 = Reactor 2; P3 = Reactor 3; P4 = Reactor 4 and E = Efficiency.

\begin{tabular}{|c|c|c|c|c|c|c|c|}
\hline Parameters & P1 & $\mathbf{P 2}$ & $\begin{array}{l}\text { E. (\%) } \\
\text { P1-P2* }\end{array}$ & P3 & $\begin{array}{c}\text { E. (\%) } \\
\text { P1-P3** }\end{array}$ & P4 & $\begin{array}{c}\text { E. (\%) } \\
\text { P1-P4*** }\end{array}$ \\
\hline Water temperature ${ }^{\circ} \mathrm{C}$ & 30.4 & 28.7 & - & 28.2 & - & 29.1 & - \\
\hline Ambient temperature ${ }^{\circ} \mathrm{C}$ & 33.0 & 33.0 & - & 33.0 & - & 33.0 & - \\
\hline Turbidity (UNT) & 19.3 & 4.6 & 76.2 & 0.9 & 95.3 & 0.9 & 95.3 \\
\hline Conductivity $\left(\mu \mathrm{S} . \mathrm{cm}^{-1}\right)$ & 199.5 & 185.6 & 7.0 & 219.0 & -9.8 & 174.0 & 12.8 \\
\hline $\mathrm{pH}$ & 8.0 & 6.8 & - & 6.5 & - & 5.9 & - \\
\hline Total nitrogen $\left(\mathrm{mg} \cdot \mathrm{L}^{-1}\right)$ & 8.7 & 8.4 & 3.4 & 8.0 & 8.0 & 7.7 & 11.5 \\
\hline Dissolved oxygen $\left(\mathrm{mg} . \mathrm{L}^{-1}\right)$ & 8.3 & 8.3 & - & 7.9 & - & 8.1 & - \\
\hline Ammonia $\left(\mathrm{mg}^{-L^{-1}}\right)$ & 0.2 & 0.1 & 50.0 & 0.5 & -150.0 & 0.4 & -100.0 \\
\hline $\mathrm{CDO}\left(\mathrm{mg} \cdot \mathrm{O}_{2} \cdot \mathrm{L}^{-1}\right)$ & 12.0 & 11.0 & 8.3 & 10.0 & 16.7 & 3.0 & 75.0 \\
\hline $\mathrm{BDO}\left(\mathrm{mg} \cdot \mathrm{O}_{2} \cdot \mathrm{L}^{-1}\right)$ & 11.4 & 10.0 & 12.3 & 7.5 & 34.2 & 7.7 & 32.5 \\
\hline Apparent color $(\mathrm{Pt} / \mathrm{L})$ & 183.0 & 60.0 & 67.2 & 78.0 & 57.4 & 80.0 & 56.3 \\
\hline Total Phosphorus $\left(\mu \mathrm{g} . \mathrm{L}^{-1}\right)$ & 180.9 & 64.0 & 64.6 & 44.9 & 75.2 & 27.0 & 85.1 \\
\hline Chlorides (mg.L $\left.\mathrm{L}^{-1}\right)$ & 13.0 & 6.0 & 53.8 & 6.5 & 50.0 & 5.9 & 54.6 \\
\hline TDS (mg.L $\left.{ }^{-1}\right)$ & 94.0 & 87.0 & 7.4 & 103.0 & -9.6 & 82.0 & 12.8 \\
\hline $\mathrm{Na}\left(\mathrm{mg} \cdot \mathrm{L}^{-1}\right)$ & 9.2 & 9.4 & -2.2 & 9.3 & -1.1 & 9.2 & 0.0 \\
\hline $\mathrm{K} \quad\left(\mathrm{mg} \cdot \mathrm{L}^{-1}\right)$ & 2.6 & 0.7 & 73.1 & 1.3 & 50.0 & 1.4 & 46.2 \\
\hline $\mathrm{Si} \quad\left(\mathrm{mg} \mathrm{L}^{-1}\right)$ & 6.8 & 6.2 & 8.8 & 15.0 & -120.6 & 4.9 & 27.9 \\
\hline $\mathrm{Ca}\left(\mathrm{mg} . \mathrm{L}^{-1}\right)$ & 9.7 & 9.1 & 6.2 & 21.3 & -119.6 & 15.4 & -58.8 \\
\hline $\operatorname{Mg}\left(\mathrm{mg} \cdot \mathrm{L}^{-1}\right)$ & 7.7 & 7.2 & 6.5 & 3.1 & 59.7 & 2.2 & 71.4 \\
\hline Total coliforms MNP/100 mL & $73 \times 10^{3}$ & $6.1 \times 10^{3}$ & 91.6 & $0.1 \times 10^{3}$ & 99.9 & $0.6 \times 10^{3}$ & 99.2 \\
\hline E. coli $\mathrm{MNP} / 100 \mathrm{~mL}$ & $1.2 \times 10^{3}$ & $0.1 \times 10^{3}$ & 91.7 & 0.0 & 100.0 & 0.0 & 100.0 \\
\hline
\end{tabular}

Manfrinato (1989), using the edaphophytodepuration method for preliminary treatment of water, reported $92.3 \%$ efficiency in the reduction of turbidity after the contaminated water passed through the aquatic plants. A higher value was achieved in the system used here after 20 days, however the water treated passed through the reactor containing aquatic plants as well as the one with soil, gravel, and peat (Table 4).

Schulz et al. (2004) obtained 41.0-53.0\% efficiency in reducing total phosphorous after 56 to 70 days of treatment, respectively, and Lee et al. (2004) reported $47.0 \%$ in phases I and II, corresponding to 1 to 182 days, and $59.0 \%$ in phase II, from 183 to 244 days. The results showed a maximum efficiency of $97.4 \%$ at 20 days (Table 4 ) in the system-containing reactor 4, representing an improvement compared to the results obtained by Lee et al. (2004).

In the systems studied here, that made up of reactors 2 and 4 proved to be more efficient. In the beginning of the experiment, $\mathrm{T} 0$, in the system contend reactors 2 and 4 had been observed the biggest efficiencies for the values reduction of conductivity, apparent color, $\mathrm{Na}$ and $\mathrm{Mg}$. In the T10 period, in this same system, had occurred the biggest efficiencies for the reduction of the CDO, chlorides and $E$. coli.

The biggest efficiencies had been verified in the T15 period for total nitrogen and total coliforms and in the T20, for turbidity, total phosphorus, TDS and $\mathrm{Si}$. The reactor only contends floating aquatic plant provided the biggest efficiencies for $\mathrm{K}$ and $\mathrm{Ca}$, in the $\mathrm{T} 20$.

The results had demonstrated that bigger efficiencies for the treatment of the water of the used river had occurred in the system contend a reactor contend floating aquatic plant together with another reactor contend gravel, ground and peat.

Jing et al. (2001) conducted research-using CWs to treat river water and obtained 13.0 to $51.0 \%$ efficiency in the reduction of CDO. 
Table 3 - Analyses of water parameters of Corumbataí River, in period T15 days, in CWs. Legend: P1 = Reactor 1; $\underline{\mathrm{P} 2=\text { Reactor } 2 ; \mathrm{P} 3=\text { Reactor } 3 ; \mathrm{P} 4=\text { Reactor } 4 \text { and } \mathrm{E}=\text { Efficiency. }}$

\begin{tabular}{|c|c|c|c|c|c|c|c|}
\hline Parameters & P1 & $\mathbf{P 2}$ & $\begin{array}{l}\text { E. }(\%) \\
\text { P1-P2* }\end{array}$ & $\mathbf{P 3}$ & $\begin{array}{c}\text { E. }(\%) \\
\text { P1-P3** }\end{array}$ & $\mathbf{P 4}$ & $\begin{array}{c}\text { E. (\%) } \\
\text { P1-P4*** }\end{array}$ \\
\hline Water temperature ${ }^{\circ} \mathrm{C}$ & 29.7 & 28.0 & - & 28.5 & - & 31.5 & - \\
\hline Ambient temperature ${ }^{\circ} \mathrm{C}$ & 33.0 & 33.0 & - & 33.0 & - & 33.0 & - \\
\hline Turbidity (UNT) & 8.5 & 5.4 & 36.5 & 0.9 & 89.4 & 0.9 & 89.4 \\
\hline Conductivity $\left(\mu \mathrm{S} . \mathrm{cm}^{-1}\right)$ & 186.2 & 180.2 & 3.2 & 203.0 & -9.0 & 174.7 & 6.2 \\
\hline $\mathrm{pH}$ & 7.5 & 6.6 & - & 6.3 & - & 6.3 & - \\
\hline Total nitrogen $\left(\mathrm{mg} \mathrm{L}^{-1}\right)$ & 9.8 & 9.4 & 4.1 & 9.1 & 7.1 & 8.4 & 14.3 \\
\hline Dissolved oxygen $\left(\mathrm{mg} \cdot \mathrm{L}^{-1}\right)$ & 7.5 & 6.8 & - & 4.2 & - & 3.9 & - \\
\hline $\operatorname{Ammonia}\left(\mathrm{mg} \cdot \mathrm{L}^{-1}\right)$ & 0.12 & 0.17 & -41.7 & 0.5 & -316.7 & 0.3 & -150.0 \\
\hline $\mathrm{CDO}\left(\mathrm{mg} \cdot \mathrm{O}_{2} \cdot \mathrm{L}^{-1}\right)$ & 20.0 & 24.5 & -22.5 & 14.0 & 30.0 & 15.5 & 22.5 \\
\hline $\mathrm{BDO}\left(\mathrm{mg} \cdot \mathrm{O}_{2} \cdot \mathrm{L}^{-1}\right)$ & 10.9 & 10.1 & 7.3 & 6.1 & 44.0 & 8.6 & 21.1 \\
\hline Apparent color $(\mathrm{Pt} / \mathrm{L})$ & 95.0 & 61.0 & 35.8 & 42.0 & 55.8 & 27.0 & 71.6 \\
\hline Total Phosphorus $\left(\mu \mathrm{g} . \mathrm{L}^{-1}\right)$ & 136.9 & 72.0 & 47.4 & 17.5 & 87.2 & 16.0 & 88.3 \\
\hline Chlorides $\left(\mathrm{mg} . \mathrm{L}^{-1}\right)$ & 8.2 & 5.1 & 37.8 & 5.6 & 31.7 & 7.0 & 14.6 \\
\hline TDS (mg.L $\left.{ }^{-1}\right)$ & 88.0 & 85.0 & 3.4 & 95.0 & -8.0 & 80.5 & 8.5 \\
\hline $\mathrm{Na}\left(\mathrm{mg} \cdot \mathrm{L}^{-1}\right)$ & 8.8 & 9.5 & -8.0 & 9.5 & -8.0 & 9.8 & -11.4 \\
\hline $\mathrm{K} \quad\left(\mathrm{mg} \cdot \mathrm{L}^{-1}\right)$ & 2.5 & 1.3 & 48.0 & 1.0 & 60.0 & 1.2 & 52.0 \\
\hline $\mathrm{Si}\left(\mathrm{mg} . \mathrm{L}^{-1}\right)$ & 6.9 & 6.5 & 5.8 & 14.4 & -108.7 & 4.5 & 34.8 \\
\hline $\mathrm{Ca}\left(\mathrm{mg} . \mathrm{L}^{-1}\right)$ & 9.7 & 9.0 & 7.2 & 19.5 & -101.0 & 16.2 & -67.0 \\
\hline $\operatorname{Mg}\left(\mathrm{mg} \cdot \mathrm{L}^{-1}\right)$ & 6.9 & 6.8 & 1.4 & 3.4 & 50.7 & 2.6 & 62.3 \\
\hline Total coliforms MNP/100 mL & $18.0 \times 10^{3}$ & $0.6 \times 10^{3}$ & 96.5 & $0.0 \times 10^{3}$ & 99.8 & $2.1 \times 10^{3}$ & 99.9 \\
\hline E. coli $\mathrm{MNP} / 100 \mathrm{~mL}$ & $0.1 \times 10^{3}$ & $0.1 \times 10^{3}$ & 0.0 & 0.0 & 100.0 & 0.0 & 100.0 \\
\hline
\end{tabular}

Table 4 - Analyses of water parameters of Corumbataí River, in period T20 days, in CWs. Legend: Legend: P1 = Reactor 1; P2 = Reactor 2; P3 = Reactor 3; P4 = Reactor 4 and $\mathrm{E}=$ Efficiency.

\begin{tabular}{|c|c|c|c|c|c|c|c|}
\hline Parameters & P1 & $\mathbf{P 2}$ & $\begin{array}{l}\text { E. }(\%) \\
\text { P1-P2 } *\end{array}$ & $\mathbf{P 3}$ & $\begin{array}{c}\text { E. }(\%) \\
\text { P1-P3** }\end{array}$ & P4 & $\begin{array}{c}\text { E. }(\%) \\
\text { P1-P4*** }\end{array}$ \\
\hline Water temperature ${ }^{\circ} \mathrm{C}$ & 28.1 & 26.3 & - & 28.6 & - & 26.4 & - \\
\hline Ambient temperature ${ }^{\circ} \mathrm{C}$ & 32.0 & 32.0 & - & 32.0 & - & 32.0 & - \\
\hline Turbidity (UNT) & 24.9 & 3.5 & 85.9 & 0.9 & 96.4 & 0.8 & 96.8 \\
\hline Conductivity $\left(\mu \mathrm{S} . \mathrm{cm}^{-1}\right)$ & 194.4 & 175.0 & 10.0 & 201.0 & -3.4 & 183.2 & 5.8 \\
\hline $\mathrm{pH}$ & 7.8 & 6.0 & - & 6.9 & - & 6.5 & - \\
\hline Total nitrogen $\left(\mathrm{mg} . \mathrm{L}^{-1}\right)$ & 9.8 & 9.4 & 4.1 & 9.5 & 3.1 & 9.1 & 7.1 \\
\hline Dissolved oxygen $\left(\mathrm{mg}^{-\mathrm{L}^{-1}}\right)$ & 7.3 & 7.2 & - & 5.5 & - & 5.7 & - \\
\hline Ammonia $\left(\mathrm{mg}^{-\mathrm{L}^{-1}}\right)$ & 0.32 & 0.26 & 18.8 & 0.5 & -56.3 & 0.4 & -25.0 \\
\hline $\mathrm{CDO}\left(\mathrm{mg} \cdot \mathrm{O}_{2} \cdot \mathrm{L}^{-1}\right)$ & 30.0 & 17.5 & 41.7 & 35.0 & -16.7 & 27.0 & 10.0 \\
\hline $\mathrm{BDO}\left(\mathrm{mg} \cdot \mathrm{O}_{2} \cdot \mathrm{L}^{-1}\right)$ & 9.1 & 8.5 & 6.6 & 5.4 & 40.7 & 5.9 & 35.2 \\
\hline Apparent color $(\mathrm{Pt} / \mathrm{L})$ & 174.0 & 74.0 & 57.5 & 79.5 & 54.3 & 74.0 & 57.5 \\
\hline Total Phosphorus $\left(\mu \mathrm{g} . \mathrm{L}^{-1}\right)$ & 186.5 & 40.1 & 78.5 & 23.3 & 87.5 & 4.8 & 97.4 \\
\hline Chlorides $\left(\mathrm{mg} . \mathrm{L}^{-1}\right)$ & 7.3 & 6.6 & 9.6 & 4.7 & 35.6 & 5.5 & 24.7 \\
\hline TDS $\left(m g . L^{-1}\right)$ & 92.0 & 66.5 & 27.7 & 93.0 & -1.1 & 56.0 & 39.1 \\
\hline $\mathrm{Na}\left(\mathrm{mg} . \mathrm{L}^{-1}\right)$ & 9.3 & 9.8 & -5.4 & 9.9 & -6.5 & 10.2 & -9.7 \\
\hline $\mathrm{K} \quad\left(\mathrm{mg} \cdot \mathrm{L}^{-1}\right)$ & 2.5 & 0.1 & 96.0 & 0.8 & 68.0 & 1.0 & 60.0 \\
\hline $\mathrm{Si} \quad\left(\mathrm{mg} \cdot \mathrm{L}^{-1}\right)$ & 7.1 & 6.7 & 5.6 & 13.8 & -94.4 & 3.9 & 45.1 \\
\hline $\mathrm{Ca}\left(\mathrm{mg} \cdot \mathrm{L}^{-1}\right)$ & 10.3 & 8.2 & 20.4 & 19.5 & -89.3 & 15.6 & -51.5 \\
\hline $\operatorname{Mg}\left(\mathrm{mg} . \mathrm{L}^{-1}\right)$ & 7.1 & 6.5 & 8.5 & 3.9 & 45.1 & 2.9 & 59.2 \\
\hline Total coliforms MNP/100 mL & $54 \times 10^{3}$ & $1.9 \times 10^{3}$ & 96.5 & $0.7 \times 10^{3}$ & 98.6 & $0.4 \times 10^{3}$ & 99.3 \\
\hline E. coli $\mathrm{MNP} / 100 \mathrm{~mL}$ & $0.2 \times 10^{3}$ & 0.0 & 100.0 & 0.0 & 100.0 & 0.0 & 100.0 \\
\hline
\end{tabular}

Ansola et al. (2003), verifying the performance of the CW system, obtained better results than Jing et al. (2001), successfully reducing CDO by $80.0-$ $89.0 \%$, BDO by $82.0-87.0 \%$, and $E$. coli by 
99.9\%. Nor these results had always been similar to those found here, probably had to the different used systems, environmental conditions of the process, design and other factors.

In summary, the system studied here obtained the best performance for: turbidity, $96.8 \%$ at T20; conductivity, $18.7 \%$ at $\mathrm{T} 0$; total nitrogen, $14.3 \%$ at T20; ammonia, $71.4 \%$ at T0; CDO, $75.0 \%$ at $\mathrm{T} 5$; $\mathrm{BDO}, 44.0 \%$ at $\mathrm{T} 15$; apparent color, $75.3 \%$ at $\mathrm{T} 0$; total phosphorous, $97.4 \%$ at T20; chlorides, $54.6 \%$ at T10; TDS, $39.1 \%$ at T20; Na, $64.4 \%$ at T0; K, $96.0 \%$ at $\mathrm{T} 20 ; \mathrm{Si}, 45.1 \%$ at $\mathrm{T} 20 ; \mathrm{Ca}, 20.4 \%$ at $\mathrm{T} 20 ; \mathrm{Mg} 80.5 \%$ at T0; total coliforms, $99.9 \%$ at T10 and T15; and E. coli, $100.0 \%$ at T10, T15, and $\mathrm{T} 20$.

\section{CONCLUSIONS}

The CW system studied here proved to be effective in treating river water, mainly the system composed of the reactor containing aquatic plants with other reactor containing three different sizes of gravel plus soil of cerrado area and peat, achieving maximum efficiency for the most of the parameters studied, although at different retention times. However, a trust of floating aquatic plants could produce bigger efficiencies of the systems for the reduction of pollutant components in waters of the rivers. Bigger efficiencies above of $85 \%$ had only been verified for turbidity, total phosphorus, total coliforms, E.coli and K.

\section{RESUMO}

$\mathrm{Na}$ intenção de reduzir nutrientes e microrganismos das águas de rio, foi estudado um processo alternativo de tratamento, como o sistema construído de áreas alagadas (CWs), em escala de laboratório. Os parâmetros analisados em diferentes pontos do sistema utilizado foram amônia, demanda bioquímica de oxigênio (DBO), demanda química de oxigênio (DQO), cloretos, cor aparente, condutividade, oxigênio dissolvido, magnesium $(\mathrm{Mg})$, sodium $(\mathrm{Na})$, potassium $(\mathrm{K})$, silicium ( $\mathrm{Si}$ ), fósforo total, coliformes totais e Escherichia coli, sólidos totais dissolvidos (TDS), turbidez e biomassa da macrófita. Os resultados demonstraram que este sistema alternativo de tratamento de água do rio Corumbataí foi eficiente na remoção dos microrganismos: coliformes totais e Escherichia coli dentre outros parâmetros analisados, em diferentes tempos de tratamento, promovendo melhoria acentuada na qualidade da água tratada.

\section{ACKNOWLEDGEMENTS}

We are grateful to the CEA/UNESP and Department of Biochemistry and Microbiology/UNESP, Rio Claro, SP, Brazil. Support: FAPESP, Process no 99/02881-5. We are especially grateful to Eleni Nadai Malagutti, Francisca de Assis Mattioli Gonçalves and Sara Cristina Galvão.

\section{REFERENCES}

Ansola, G.; González, J. M.; Cortijo, R. and Luis, E. (2003), Experimental and full-scale pilot plant constructed wetlands for municipal wastewater treatment. Ecol. Eng., 21, 43-52.

Billore, S. K., Singh N., Sharma J. K. and Nelson R. M. (1999), Horizontal subsurface flow gravel bed constructed wetland with Phragmites karka in central India. Wat. Sci. and Tech., 40, 163-171.

Braskerud, B. C. (2002a), Factors affecting nitrogen retention in small constructed wetlands treating agricultural non-point source pollution. Ecol. Eng. 18, 351-370.

Braskerud, B. C. (2002b), Factors affecting phosphorus retention in small constructed wetlands treating agricultural non-point source pollution. Ecol. Eng. 19, 41-61.

Brix, H. (1993), The use of aquatic macrophytes in water removal processes, and treatment performance. Wat. Res., 24, 229-266.

CONAMA (Conselho Nacional do Meio Ambiente) (2005), Resoluções do CONAMA. 5th ed., Brasilia, 78-95.

Cooper, P. F. and Findlater, B. C. (1990), Constructed Wetlands in Water Pollution Control. Pergamon Press, Oxford, UK.

Domingos, R. N.; Angelis, D. F., Bello, A R C. (2005), Ultrasound efficiency in relation to sodium hipohlorite and filtration adsorptian in microbial elimination in a water treatment plant.. Braz. Arch. Biol. and Tech., 48, 739-745. 2005.

Elias, J. M., Salati Filho E. and Salati, E. (2001), Performance of constructed wetland system for public water supply. Wat. Sci. and Tech., 44, 579-584.

Gersberg, R. M., Elkins, B. V., Lyon, S. R. and Goldman, C. R. (1986), Role of aquatic in wastewater treatment by artificial wetlands. Wat. Res., 20, 363368. 
Gómez Cerezo, R., Suárez, M. L. and Vidal-Abarca, M. R. (2001), The performance of a multi-stage system of constructed wetlands for urban wastewater treatment in a semiarid region of SE Spain. Ecol. Eng., 16, 501-517.

Green, M.; Safry, I. and Agami, M. (1996), Constructed wetlands for river reclamation: experimental design, start-up and preliminary results. Biores. Tech., 55, 157-162.

Furtado, A. L. S.; Casper, P. and Esteves, F. A. (2002), Methanogenesis in na impacted and two dystrophic coastal lagoons (Macaé, Brazil). Braz. Arch. Biol. Technol. 45, 195-202.

Hammer, D. A. (1989), Constructed Wetlands for Wastewater Treatment: Municipal, Industrial and Agricultural. Lewis Publishers, Chelsea, MI, USA, pp. 100-150.

Haynes, R. J. and Goh, K. M. (1978), Ammonium and nitrate nutrition of plants. Biol. Rev., 53, 495-505.

Jing, S. R.; Lin, Y. F.; Lee, D. Y. and Wang, T. W. (2001), Nutrient removal from polluted river water by using constructed wetlands. Biores. Tech., 76, 131135.

Kadlec, R. H. and Knight, R. L. (1996), Treatment Wetlands. Lewis Publishers, Boca Raton, FL, USA, pp. 15-120.

Koottatep, T. and Polprasert, C. (1997), Role of plant uptake on nitrogen removal in constructed wetlands located in the tropics. Wat. Sci. and Tech., 36, 1-8.

Lee, C.Y.; Lee, C. C.; Lee, F. Y.; Tseng, S. K. and Liao, C. J. (2004), Performance of subsurface flow constructed wetland taking pretreated swine effluent under heavy loads. Biores. Tech., 92, 173-179.

Manfrinato, E. S. (1989), Avaliação do método edafofitodepuração para tratamento preliminar de águas. Dissertação (Mestrado em Agronomia) - Escola Superior "Luiz de Queiroz", Universidade de São Paulo, Piracicaba, Brasil.

Mitsch, W. J.; Horne, A. and Nairn, R.W. (2000), Nitrogen and phosphorus retention in wetlands (special issue). Ecol. Eng., 14, 1-206.

Moshiri, G. A. (1993), Constructed Wetlands for water Quality Improvement. Lewis Publishers, Boca Raton, FL, USA.

Neralla, S., Weaver, R. W., Lesikar, B. J.(1998), Plant selection for treatment of septic effluent in subsurface wetlands. ASAE, on-site wastewater treatment. Paper presented at Eighth National Symposium on Individual and Small Community. Sewage Syst, Orlando, FL, USA.

Nguyen, L. M. (2000), Organic matter composition, microbial biomass and microbial activity in gravelbed constructed wetlands treating farm dairy wastewaters. Ecol. Eng., 16, 199-221.

Olson, R. K. and Marshall, K. (1992), The role of created and natural wetlands in controlling non point source pollution (special issue). Ecol. Eng., 1, 1-170.
Palma-Silva, G. M., Tauk-Tornisielo, S. M. (2001), La contribucion de las areas urbanas en la polucion del rio Corumbatai, SP, Brazil. Paper presented at VII Taller de la Catedra de Medio Ambiente, Havana, Cuba. Cátedra de Medio Ambiente. Contribucion a la Educacion y la Proteccion Ambiental. Habana, Cuba: nstituto de Ciencia Tecnologia y Medio Ambiente, 2, pp.1-9.

Pant, H. K.; Reddy, K. R. and Lemon, E. (2001), Phosphorus retention capacity of root bed media of subsurface flow constructed wetlands. Ecol. Eng., 17, 345-355.

Pant, H. K. and Reddy, K. R. (2003), Potential internal loading of phosphorus in a wetland constructed in agricultural land. Wat. Res., 37, 965-972.

Perkins, J. and Hunter, C. (2000), Removal of enteric bacteria in a surface flow constructed wetland in Yorkshire, England. Wat. Res., 34, 1941-1947.

Rebouças, A. C.; Braga, B. and Tundisi, J. G. (1999), Águas Doces no Brasil: capital ecológico, uso e conservação. São Paulo: Escrituras, 1-36.

Salati E., Salati E., Salati, E., Tauk-Tornisielo, S. M., Brega, D. F. and Bombonato, C. J. (1999), Use of the HDS System (Hydric Depuration with Soils) Associated to Other Constructed Wetlands Techniques for Public Water Supply. Wat. Scien. and Tech., 40, 203-209.

Schulz C., Gelbrecht J.and Rennert, B. (2004), Constructed wetlands with free water surface for treatment of aquaculture effluents. J. Appl. Ichthyol., 20, 64-70.

Söderqvist, T. (2002), Constructed wetlands as nitrogen sinks in southern Sweden: an empirical analysis of cost determinants. Ecol. Eng., 19, 161-173.

Solano, M. L., Soriano, P. and Ciria, M. P. (2004), Constructed Wetlands as a Substainable Solution for Wastewater Treatment in Small Villages. Biosyst. Eng., 87, 109-118.

Souza, A. D. G. and Tundisi, J. G. (2003). Water quality in watershed of the Jaboatão River (Pernambuco, Brazil): a case study. Braz. Arch.Biol. Technol .46, 709-719.

Standard Methods for the Examination of Water and Wastewater (1998), 20th ed, American Public Health Association/American Water Works Association/Water Environment Federation, Washington DC, USA.

Stober, J., O’Connor, J. T. and Brazos, B. J. (1997), Winter and spring evaluations of a wetland for tertiary wastewater treatment. Wat. Env. Res., 69, 961-968.

Received: July 26, 2006; Revised: October 26, 2007; Accepted: June 20, 2008. 